\title{
Effect of Coconut Water on Physical Characteristics and Yield of Vanilla planifolia Fruit
}

\author{
Pérez-Orozco, Zayra Guadalupe ${ }^{1}$; Delgado-Alvarado, Adriana ${ }^{1}$; Herrera-Cabrera, Braulio Edgar ${ }^{1}$; \\ Arévalo-Galarza, Ma. de Lourdes ${ }^{2}$; Jaramillo-Villanueva, José Luis ${ }^{1}$ \\ 1 Colegio de Postgraduados, Campus Puebla. Boulevard Forjadores de Puebla 205, Col. Santiago Momoxpan, \\ San Pedro Cholula, Puebla, CP 72760. México. \\ 2 Colegio de Postgraduados Campus Montecillo. Carretera México-Texcoco km 36.5, Montecillo, Texcoco, \\ Estado de México. CP 56230. México. \\ * Corresponding author: adah@colpos.mx, adriana_dh@hotmail.com
}

Gitation: Pérez-Orozco, Z. G. Delgado-Alvarado, A., HerreraCabrera, B. E., Arévalo-Galarza, Ma. de L., \& Jaramillo-Villanueva, J. L (2021). Effect of Coconut Water on Physical Characteristics and Yield of Vanilla planifolia Fruit. Agro Productividad. https://doi.org/10.32854 agrop.v14i8.2076

Editor in Chief: Dr. Jorge Cadena Iñiguez

Received: February, 2021

Accepted: August, 2021.

Estimated publication date: September, 2021

This work is licensed under a Creative Commons Attribution-NonCommercial 4.0 International license.

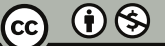

\section{ABSTRACT}

Objective: To evaluate the effect of coconut water spray on the physical characteristics and yield of vanilla fruit and to identify the relationship between environmental variables and yield components in Gutiérrez Zamora, Veracruz, Mexico.

Design/Methodology/Approach: The study was conducted in a 3- to 4-year-old vanilla plantation under shade mesh with bamboo stakes as support. The variables measured were fruit and plant dimensions, weight, yield components, and environmental variables (temperature, relative humidity, and photosynthetically active radiation, PAR). Beginning at flowering, the plants were sprayed every two weeks for three months with one of four treatments (T1: 100\% water; T2: 50\% coconut water; T3: 100\% coconut water; and T4: Megafol solution) at two sites within the same vanilla plantation. Statistical analysis consisted of ANOVA, comparison of means, and canonical correlation analysis.

Results: The highest averages of fruit dimensions and weight were obtained from Site 1. T2 and T3 fruits were heavier than T1 and T4 fruits. The canonical correlation analysis showed that PAR and relative humidity were related in different ways to yield component variables in function of the vanilla plantation site.

Study Limitations/Implications: Using coconut water as an organic alternative for fertilization can decrease application of chemical substances and reduce production costs, among other advantages.

Findings/Conclusion: Coconut water applied at the beginning of the vanilla flowering stage has a significant effect on fruit dimensions and on the accumulation of fruit dry matter and may be an organic option for supplying nutrients and increasing vanilla yield.

Keywords: Cocos nucifera L., organic fertilizer, yield, environment.

\section{INTRODUCTION}

In 2019, Mexico produced 850.4 tons of vanilla, production that was distributed over four states: Veracruz (Totonacapan region) with approximately $80 \%(679.5 \mathrm{t}$ ) of the country's total production, Oaxaca with 10.11\% (86 t), Puebla with 7.74\% (65.9 t), and San Luis Potosí with 2.23\% (19 t) (SIAP, 2019). 
Vanilla can be cultivated in various ways. It can be grown in acahual, or secondary vegetation, or intensively with live or inert supports. In the Totonacapan region, the two most used systems are in acahual and under shade mesh (Espinoza-Pérez et al., 2018). In acahual, the plant obtains most of its nutrients from the organic matter that accumulates on the soil when the support tree loses its leaves (Barrera-Rodríguez et al., 2009), while management and monitoring is easier under shade mesh, and agrochemical application and irrigation is controlled (Hernández-Hernández, 2014). Because vanilla cultivation depends essentially on organic nutrition and traditional management, vanilla plantations lack a management system that standardizes variables such as the amount and quality of organic matter that should be incorporated (González-Chávez et al., 2018). For this reason, in terms of establishment and maintenance of vanilla plantations, one of the main challenges is to maintain adequate plant nutrition (Carrillo-González \& GonzálezChávez, 2018), which has positive effects on number of inflorescences, flower budding, number of fruits, and fruit size, among other variables (Diez et al., 2018). Naturally, these variables can also depend on management, water availability, solar radiation, and temperature (Rocha-Flores et al., 2018). Vanilla is a species that is highly sensitive to climate events (Borbolla-Pérez et al., 2016), and for this reason, production on the national level is low.

It has been documented that coconut (Cocos nucifera L.) fruit promotes plant growth because of its content of phytohormones (Sandoval-Prando et al., 2014), such as cytokines, which are known to play an important role in plant growth and development (Ge et al., 2006). Several studies have found that coconut water contains diverse organic compounds and mineral nutrients that are important for plant development (Ramírez-Luna et al., 2005; Vieira de Souza et al., 2013; Sandoval-Prando et al., 2014). Worldwide, Mexico is eighth in the production of coconut palm, contributing $1.7 \%$ of the world production. This palm is found in mostly in tropical regions (SAGARPA, 2017), and the tropical state of Veracruz is one of the main producer states of C. nucifera L. as well as of Vanilla planifolia L. For this reason, we propose the application of coconut water in the cultivation of vanilla to make use of the plant genetic resources that exist in the region. The objective of this study was to evaluate the effect of applying coconut water at different concentrations on physical characteristics and yield of vanilla fruit, as well as to determine the relationship between yield components and environmental variables at two sites of the same vanilla plantation in Paso de Barriles, Gutiérrez Zamora, Veracruz.

\section{MATERIALS AND METHODS}

\section{Study Sites}

The study was conducted during the 2019 crop cycle in a vanilla plantation established with inert supports (bamboo) in a system under 50\% shade mesh. The vanilla plantation is found in the locality Paso de Barriles, Gutiérrez Zamora, Veracruz, at -97.123611 $\mathrm{W}$ and $20.443056 \mathrm{~N}$, at an altitude of $20 \mathrm{~m}$. Two experiments were established in the vanilla plantation: Site 1 was placed on the northern side of the plantation and Site 2 on the southern side to determine the possible effects of the treatments in different locations within the same plantation. 


\section{Applied Treatments}

The experiment consisted of applying four treatments at each site. The treatments were T1: control (400 mL of potable water), T2: $400 \mathrm{~mL}$ of water from tender coconut (C. nucifera L.) diluted (50\%) with potable water, T3: $400 \mathrm{~mL}$ coconut water $(100 \%)$, and T4: $400 \mathrm{~mL}$ of the biostimulant MEGAFOL (Valagro ${ }^{\circledR}$ ) (Figure 1), which contains vitamins, amino acids and proteins, betaines, and growth factors, as well as organic carbon, potassium oxide, total nitrogen and organic nitrogen, applied at the dose recommended by the manufacturer $\left(3 \mathrm{~mL} \mathrm{~L}^{-1}\right)$. Treatments were applied by directly spraying the flowers two weeks after the beginning of the flowering period (MarchApril), in the morning (9 to 10 a.m.), every other week for three months.

\section{Evaluated Variables}

The variables used in the evaluation of vanilla yield were selected from Rocha-Flores et al. (2018). The following plant variables were recorded: plant height, cutting thickness, number of vines $/ \mathrm{m}^{2}$, number of racemes/vine, number of racemes $/ \mathrm{m}^{2}$, number of fruits/ vine, number of fruits/raceme, number of fruits $/ \mathrm{kg}$, number of fruits $/ \mathrm{m}^{2}$, total fruit weight/ $\mathrm{m}^{2}$, and yield in $\mathrm{g} / \mathrm{m}^{2}$. To evaluate the physical characteristics of the fruits, six variables were used: length, width, thickness, length $\times$ width, volume, and weight. Length was measured with a measuring tape $(\mathrm{cm})$; width and thickness were determined $(\mathrm{cm})$ with a digital Vernier (Mitutoyo 500 Digimatic ABSOLUTE); fruits were weighed (g) with a digital balance (ADAM, model HCB3001).

\section{Environmental Variables}

From February to October 2019, data on temperature $\left({ }^{\circ} \mathrm{C}\right)$, relative humidity (\%) and luminosity, which was transformed to photosynthetically active radiation, PAR $\left(\mu \mathrm{mol} \cdot \mathrm{m}^{-2} \cdot \mathrm{s}^{-1}\right)$, were recorded with a datalogger U12-012 (Onset HOBO) at the two sites in the vanilla plantation.

\section{Experimental Design and Statistical Analysis}

At each site, four treatments with 10 replications each were evaluated. The useful plot consisted of a linear line of plants. An analysis of variance (ANOVA) was performed with the data on quantified traits within and between sites under a completely randomized

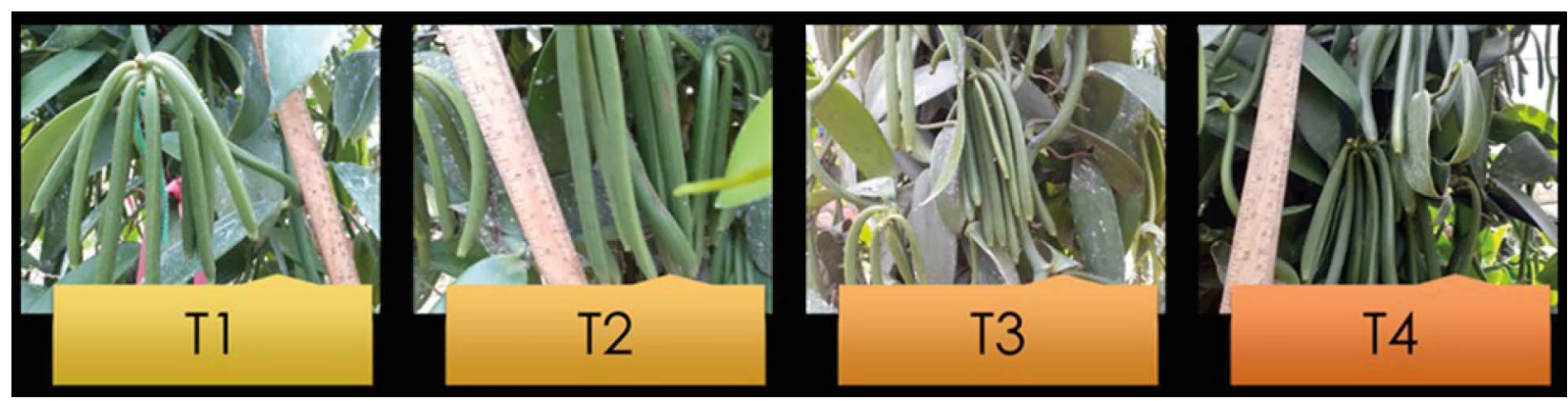

Figure 1. Vanilla fruits with the application of the treatments: $\mathrm{T} 1=100 \%$ potable water (control); $\mathrm{T} 2=50 \%$ coconut water; $\mathrm{T} 3=100 \%$ coconut water; T4= Megafol $\left(\right.$ Valagro $\left.^{\circledR}\right)$. 
blocks design (PROC GLM SAS) with SAS statistical software (SAS, 2004). Comparison of means was calculated based on the harmonic mean (n) with Tukey's test for all the variables. With the aim of relating the dataset on biological variables and the climate variables, an analysis of canonical correlations (ACG) was performed.

\section{RESULTS AND DISGUSSION}

\section{Analysis of the Effect of Treatments on Physical Fruit Characteristics of Vanilla planifolia}

The analysis of variance indicated that there were statistical differences in fruit variables between sites $(\mathrm{P} \leq 0.001)$ and treatments $(\mathrm{P} \leq 0.05)$. The coefficient of variation ranged from 3.79 and $13.66 \%$, indicating that the data is reliable. Fruits from Site 1 had significantly higher values in fresh weight, dimensions, and volume than those from Site 2. The difference was possibly due to earlier (two weeks) application of the treatments in Site 1. In this respect, González et al. (2007) point out that cauliflower growth was higher when application of gibberellic acid was made - at a certain concentration - at an early stage after planting than when application was later. Also, the first site on the northern part of the plantation receives sunlight earlier than the second site, so that temperature, humidity and PAR may have been different.

Fruit weight, length, and thickness are characteristics related to vanilla's physical quality (NMX-FF-074-SCFI-2009). Table 1 shows that spraying foliage with coconut water at different concentrations had a significant effect on these characteristics. For example, the fruit from plants treated with 50\% (T2) and 100\% coconut water (T3) had heavier fresh weights that were significantly different from the control (T1) and from the Megafol treatment (T4). The length, thickness, and volume of fruits from treatments T2, T3, and T4 had higher values than those of T1. However, T2 was significantly different from $\mathrm{T} 1$ in length only, while in thickness and volume only $\mathrm{T} 3$ was significantly different form T1 (Table 1). These results suggest that coconut water at concentrations of $50 \%$ or more has a positive impact on vanilla fruit weight and dimensions; that is, on their physical quality.

Table 1. Fresh weight and dimensions of Vanilla planifolia fruits after four treatments at two sites in a vanilla plantation in Paso de Barriles, Gutiérrez Zamora, Veracruz.

\begin{tabular}{c|c|c|c|c|c|c|c}
\multicolumn{2}{c}{ Factor } & Weight $(\mathbf{g})$ & Length $(\mathbf{c m})$ & Width $(\mathbf{c m})$ & $\begin{array}{c}\text { Thickness } \\
(\mathbf{c m})\end{array}$ & $\begin{array}{c}\text { Length/ } \\
\text { width }\left(\mathbf{c m}^{2}\right)\end{array}$ & $\begin{array}{c}\text { Volume } \\
\left(\mathbf{c m}^{3}\right)\end{array}$ \\
\hline \multirow{4}{*}{ Site } & 1 & $8.852^{\mathrm{a}}$ & $15.934^{\mathrm{a}}$ & $1.032^{\mathrm{a}}$ & $0.837^{\mathrm{a}}$ & $16.475^{\mathrm{a}}$ & $13.880^{\mathrm{a}}$ \\
\cline { 2 - 8 } & 2 & $6.892^{\mathrm{b}}$ & $14.713^{\mathrm{b}}$ & $0.946^{\mathrm{b}}$ & $0.756^{\mathrm{b}}$ & $13.921^{\mathrm{b}}$ & $10.557^{\mathrm{b}}$ \\
\cline { 2 - 8 } & DMS & 0.335 & 0.259 & 0.023 & 0.021 & 0.567 & 0.743 \\
\hline \multirow{5}{*}{ Treatment } & T1 & $7.165^{\mathrm{b}}$ & $14.983^{\mathrm{b}}$ & $0.975^{\mathrm{a}}$ & $0.770^{\mathrm{b}}$ & $14.628^{\mathrm{a}}$ & $11.331^{\mathrm{b}}$ \\
\cline { 2 - 8 } & $\mathrm{T} 2$ & $8.232^{\mathrm{a}}$ & $15.557^{\mathrm{a}}$ & $0.993^{\mathrm{a}}$ & $0.806^{\mathrm{ab}}$ & $15.510^{\mathrm{a}}$ & $12.619^{\mathrm{ab}}$ \\
\cline { 2 - 8 } & $\mathrm{T} 3$ & $8.608^{\mathrm{a}}$ & $15.438^{\mathrm{ab}}$ & $1.007^{\mathrm{a}}$ & $0.810^{\mathrm{a}}$ & $15.578^{\mathrm{a}}$ & $12.770^{\mathrm{a}}$ \\
\cline { 2 - 8 } & $\mathrm{T} 4$ & $7.484^{\mathrm{b}}$ & $15.315^{\mathrm{ab}}$ & $0.981^{\mathrm{a}}$ & $0.802^{\mathrm{ab}}$ & $15.075^{\mathrm{a}}$ & $12.155^{\mathrm{ab}}$ \\
\cline { 2 - 8 } & DMS & 0.625 & 0.483 & 0.044 & 0.039 & 1.058 & 1.387 \\
\hline
\end{tabular}

$\mathrm{T} 1=100 \%$ potable water $($ control); $\mathrm{T} 2=50 \%$ coconut water; $\mathrm{T} 3=100 \%$ coconut water; $\mathrm{T} 4=$ Megafol. Different letters in a row indicate significant difference (Tukey; $\mathrm{P} \leq 0.05$ ). 
These results agree with those of Buah \& Agu-Asare (2014), who compared the effect of coconut water $(\mathrm{CW})$ from fresh and dry fruits against benzyl amino purines -a synthetic cytokinin- on in vitro growth of banana. The best results were obtained with CW from fresh fruits on the variables number of roots, plant height, number of leaves, and fruit fresh and dry weight. CW increases the content of nitrogen in leaves, which is important in forming plant enzymes and hormones (Al-hasnawi, 2018), as well as in inducing cell division for more rapid growth (Peixe et al., 2007).

\section{Relationship between Environmental Variables and Yield Components}

The analysis of canonical correlation (Table 2) included yield component variables (number of vines/plant, plant height, support height, distance between supports, cutting thickness) and fruit variables (length, width, thickness and weight) (Rocha-Flores et al., 2018). These analyses revealed that some environmental variables had different effects on certain yield components in the sites where the experiments were conducted.

In Site 1, located on the northern side of the vanilla plantation, there was a moderate correlation $\left(0.545\right.$ and $\left.r^{2}=0.297\right)$ between environmental variables and yield components. The highest correlation was found between relative humidity at 10 a.m. (-0.0041) and number of vines $/ \mathrm{m}^{2}(0.1734)$, and between relative humidity and number of racemes/vine (0.0292). Moreover, PAR at 2 p.m. (0.4336) and at 6 p.m. (0.4568) strongly correlated with fruit weight $(-0.1921)$, length $(-0.3180)$ and thickness $(-0.1931)$ (Table 2$)$. This correlation could be explained by photosynthesis, which is the orchid's principal means of

Table 2. Canonical correlation between environmental variables and Vanilla planifolia yield component (YC) variables, Site 1, and Site 2 in the locality of Paso de Barriles, Gutiérrez Zamora, Veracruz, Mexico.

\begin{tabular}{|c|c|c|}
\hline & \multicolumn{2}{|c|}{$\begin{array}{l}\text { Correlation between environmental } \\
\text { variables and canonical YG variables }\end{array}$} \\
\hline & Site 1 & Site 2 \\
\hline Temperature $\left({ }^{\circ} \mathrm{C}\right)-6$ p.m. & -0.0177 & 0.3130 \\
\hline Relative humidity (\%) - 10 a.m. & -0.0041 & -0.1623 \\
\hline $\operatorname{PAR}\left(\mu \mathrm{mol} \cdot \mathrm{m}^{-2} \cdot \mathrm{s}^{-1}\right)-2 \mathrm{p} . \mathrm{m}$ & 0.4336 & -0.4678 \\
\hline \multirow[t]{3}{*}{$\operatorname{PAR}\left(\mu \mathrm{mol} \cdot \mathrm{m}^{-2} \cdot \mathrm{s}^{-1}\right)-6 \mathrm{p} . \mathrm{m}$} & 0.4568 & -0.4191 \\
\hline & \multicolumn{2}{|c|}{$\begin{array}{l}\text { Correlation between } \mathrm{YC} \text { variables and } \\
\text { canonical environmental variables }\end{array}$} \\
\hline & Site 1 & Site 2 \\
\hline Num. racemes/vine & 0.0292 & 0.0128 \\
\hline Weight (g) & -0.1921 & 0.4089 \\
\hline Length $(\mathrm{cm})$ & -0.3180 & -0.0226 \\
\hline Thickness (cm) & -0.1931 & 0.0461 \\
\hline Num. racemes $/ \mathrm{m}^{2}$ & 0.0067 & -0.0025 \\
\hline Num. vines $/ \mathrm{m}^{2}$ & 0.1734 & 0.3065 \\
\hline $\mathrm{R}^{2}$ & 0.297 & 0.353 \\
\hline Canonical correlation & 0.545 & 0.594 \\
\hline
\end{tabular}


obtaining carbon (Zhang et al., 2015); carbon fixed by photosynthesis makes up 90-95\% of plant dry weight (Flore, 1989). Figure 2A shows the structural correlation of environmental variables and yield components, in which the first two factors explain $86.4 \%$ of the total variation. Also, it also shows that higher relative humidity and PAR incidence at 2 and 6 p.m. generate a larger number of vines $/ \mathrm{m}^{2}$.

Analysis of canonical correlations for Site 2 (Table 2) indicated a moderate correlation (0.594 and $\left.\mathrm{r}^{2}=0.353\right)$ between environmental variables and yield components. PAR at 2 p.m. $(-0.4678)$ and at 6 p.m. $(-0.4191)$ had a high inverse correlation with fruit weight (0.4089) and number of vines $/ \mathrm{m}^{2}(0.3065)$, and a lower correlation with fruit thickness (0.0461) (Figure 2B). To a certain extent, this showed a different effect from the results in Site 1, suggesting that placement of the plants within the vanilla plantation affected the orchid's productivity. This is possibly due to the CAM photosynthesis pathway, in which $\mathrm{CO}_{2}$ exchange begins at night, when the stomata open, and increases during the night (Rodrigues et al., 2013). Moreover, the light intensity that vanilla receives in this schedule directly affects its capacity for dry matter accumulation. However, this is not the only factor; factors such as the plant's nutritional state, growth habit, age and habitat also have an influence (Zhang et al., 2018).

\section{GONGLUSIONS}

Coconut water applied to vanilla at the beginning of flowering had a significant effect on fruit length, width, volume, fresh weight, and accumulation of dry weight. These results were obtained with a concentration of $50 \%$ coconut water, which can be used
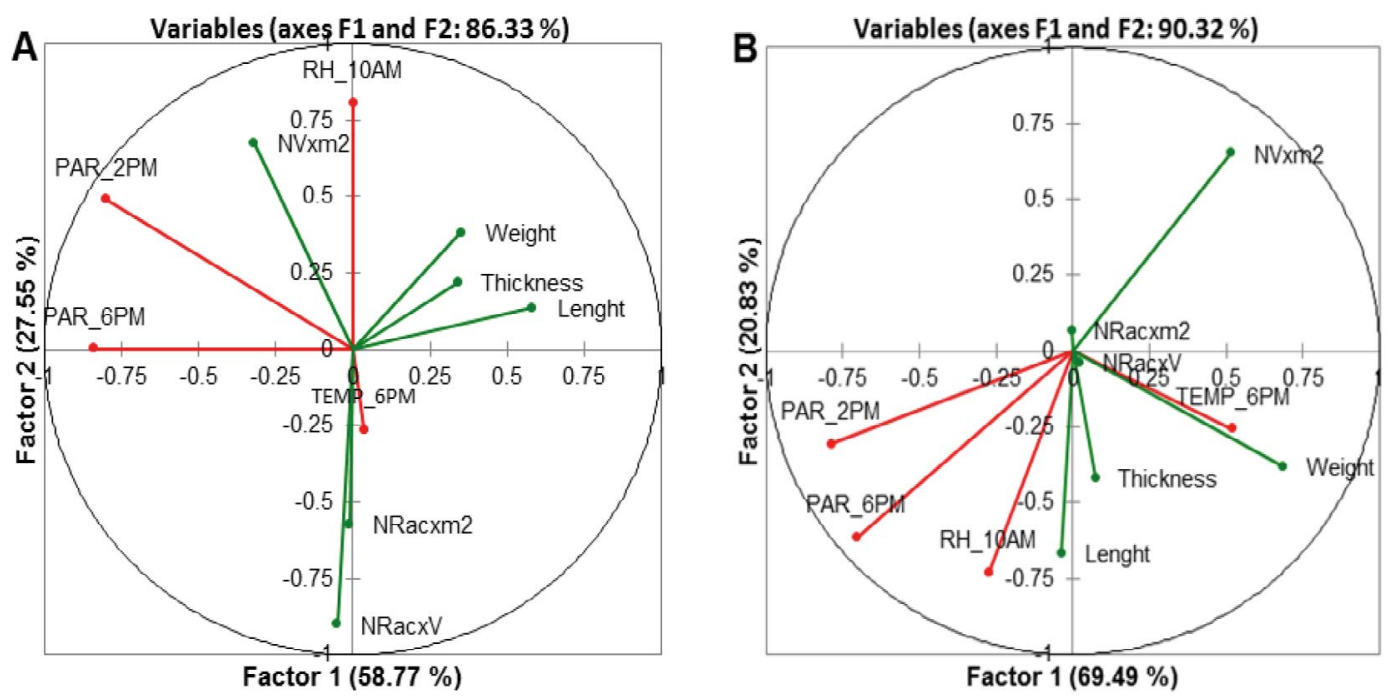

Figure 2. Graphic representation of the structural correlation coefficients of the first two factors in the interaction environmental variables $(\bullet)$ and Vanilla planifolia yield component variables $(\bullet)$ at Site 1 (A) and Site 2 (B) of the locality Paso de Barriles, Veracruz. PAR_2PM: Photosynthetically active radiation at 2 p.m.; PAR_6PM: Photosynthetically active radiation at 6 p.m.; RH_10AM: Relative humidity at 10 a.m.; TEMP_6PM: temperature at 6 p.m. NVxm ${ }^{2}$ : number of vines $/ \mathrm{m}^{2} ; \mathrm{NRacxm}{ }^{2}$ : number of racemes $/ \mathrm{m}^{2}$; NRacxV: number of racemes/vine. 
as an organic option for nutrition to increase vanilla yield. In terms of environmental effects, photosynthetically active radiation has a direct effect on fruit weight, thickness and length. The effects of coconut water and the environment should be considered among the management and crop nutrition practices for vanilla.

\section{REFERENGES}

Al-hasnawi, A. N. H. (2018). Effect of benzyladenine and chelated magnesium spraying on growth and flowering of Chrysanthemum hortorum Hort. Agricultural Research Journal, 55: 386-388.

Barrera-Rodríguez, A. I., Herrera-Cabrera, B. E., Jaramillo-Villanueva, J. L., Escobedo-Garrido, J.S. Bustamante-González, A. (2009). Caracterización de los sistemas de producción de vainilla (Vanilla planifolia A.) bajo naranjo y en malla sombra en el Totonacapan. Tropical and Subtropical Agroecosystems, 10: 199-212.

Borbolla-Pérez, V. V., Iglesias-Andreu, L.G., Herrera-Cabrera, B.E. Vovides-Papalouka, A. (2016). Aborción prematura de frutos de Vanilla planifolia Jacks. Ex Andrews. Agroprodcutividad, 9: 11.

Buah, J. N. Agu-Asare, P. (2014). Coconut water from fresh and dry fruits as an alternative to BAP in the in vitro culture of Dwarf Cavendish Banana. Journal of biological sciences, 14: 521-526.

Carrillo-González, R. González-Chávez, M.C. (2018). Relación capacidad-intensidad de potasio en los suelos no fertilizados cultivados con vainilla (Vanilla planifolia Jacks. ex Andrews). Agroproductividad, 11: 37-44.

Diez, M. C., Osorio, M. W. Moreno, F. (2016). Effect of dose and type of fertilizer on flowering and fruiting of vanilla plants. Journal of Plant Nutrition, 39: 1297-1310.

Espinoza-Pérez, J., Herrera-Cabrera, B. E., Zizumbo-Villarreal, D., Delgado-Alvarado, A. Salazar-Rojas, V. M. (2018). Perfil de productor por intensidad de manejo sobre vainilla (Vanilla planifolia Jacks. ex Andrews) en la región Totonacapan, México. Agroproductividad, 11: 58-63.

Flore, J. A. Lakso, A.N. (1989). Environmental and physiological regulation of photosynthesis in fruit crops. Horticultural Reviews, 11: 112-157.

Ge, L., Hong-Yong, J. W., Ngin-Tan, S. Shi-Ong, E. (2006). Determination of cytokinins in coconut (Cocos nucifera L.) water using capillary zone electrophoresis-tandem mass spectrometry. Electrophoresis, 27: $2171-2181$.

González, M. L., Caycedo, C., Velásquez, M. F., Flórez, V. Garzón, M. R. (2007). Efecto de la aplicación del ácido giberélico sobre el crecimiento de coliflor (Brassica oleraceae L.) var. Botrytis DC. Agronomía Colombiana, 25: 54-61.

González-Chávez, M. G., Carrillo-González, R., Villegas-Monter, A., Delgado-Alvarado, A., Perea-Vélez, S. Y. Herrera-Cabrera, B. E. (2018). Uso de vermicompost para la propagación de estacas de vainilla (Vanilla planifolia Jacks. ex Andrews). Agroproductividad, 3: 22-28.

Hernández-Hernández, J. (2014). Técnicas implementadas para el cultivo de vainilla en México. Araya Fernández et al. (Presidencia). I Seminario Internacional de Vainilla. Promoviendo la investigación, extensión y producción de vainilla en Mesoamérica. CONICIT, Costa Rica.

Lima-Morales, M., Herrera-Cabrera, B.E., Delgado-Alvarado, A., Salazar-Rojas, V.M. Campos-Contreras, J.E. (2018). Conocimiento tradicional del manejo de Vanilla planifolia Jacks Ex. Andrews (Orchidaceae) en la región huasteca de San Luis Potosí, México. Agroproductividad, 11: 51-57.

NMX-FF-074-SCFI-2009. Productos no industrializados para uso humano -vainilla- (Vanilla fragrans (Salisbury) Ames*) - especificaciones y métodos de prueba. Normas Mexicanas. Dirección General de Normas.

Peixe, A., Raposo, A., Lourenco, R., Cardoso, H. Macedo E. (2007). Coconut water and BAP successfully replaced zeatin in olive (Olea europaea L.) micropropagation. Scientia. Horticulturae, 113: 1-7.

Ramírez-Luna, E., Castillo-Aguilar, C. de la C., Aceves-Navarro, E. Carrillo-Ávila, E. (2005). Efecto de productos con reguladores de crecimiento sobre la floración y amarre de fruto en chile "habanero". Revista Chapingo Serie Horticultura, 9: 93-98.

Rocha-Flores, R. G., Herrera-Cabrera, B. E., Velasco-Velasco, J., Salazar-Rojas, V. M., Delgado-Alvarado, A. Mendoza-Castillo, M. C. (2018). Determinación preliminar de componentes de rendimiento para el cultivo de vainilla (Vanilla planifolia Jacks. ex Andrews) en la región Totonacapan, México. Agroproductividad, 11: 9-14

Rodrigues, M.A., Matiz, A., Cruz, A.B., Matsumura, A.T., Takahashi, C. A., Hamachi, L., Félix, L. M., Pereira, P. N., Latansio-Aidar, S. R., Marinho-Aidar, M. P., Demarco, A., Freschi, L., Mercier, H. Barbante-Kerbauy, G. (2013). Spatial patterns of photosynthesis in thin- and thick-leaved epiphytic orchids: unravelling C3-CAM plasticity in an organ-compartmented way. Annals of Botany, 112: 17-29. 
SAGARPA. (2017). Planeación Agrícola Nacional 2017-2030. (1era Edición). Disponible en: https://www.gob. $\mathrm{mx} / \mathrm{cms} /$ uploads/attachment/file/257086/Potencial-Vainilla.pdf

Sandoval-Prando, M. A., Chiavazza, P., Faggio A. \& Contessa C. (2014). Effect of coconut water and growth regulator supplements on in vitro propagation of Corylus avellana L. Scientia Horticulturae, 171: 91-94.

SAS, Statistical Analysis System (2004) SAS/STAT User's Guide. Version 9.1, SAS Institute Inc, Cary, North Carolina, USA. 5136 p.

SIAP. (2019). Estadística de producción agrícola 2019. Recuperado de: http://infosiap.siap.gob.mx/gobmx/ datosAbiertos_a.php

Vieira de Souza, R. A., Tavares Braga, F., Alemu Setotaw, T., Vieira Neto, J., Helena de AzevedoI, P., Helena de AzevedoI, V. \& Magela de Almeida CançadoII, G. (2013). Effect of coconut water on growth of olive embryos cultured in vitro. Ciencia Rural, 43: 290-296.

Zhang, S.B., Chen, W.Y., Huang, J.L., Bi, Y. F. Yan, X.F. (2015). Orchid species richness along elevational and environmental gradients in Yunnan, China. PLOS One 10: 1- 23.

Zhang, S., Yang, Y., Jiawei, L., Qin, J., Zhang, W., Huang, W. Hu H. (2018). Physiological diversity of orchids. Plant Diversity, 40: 196-208. 